\title{
'Pre-Neolithic' in Southeast Europe: a Bulgarian perspective
}

\author{
Maria Gurova ${ }^{1}$, Clive Bonsall 2 \\ 1 National Institute of Archaeology with Museum, Bulgarian Academy of Sciences, BG \\ gurovam@yahoo.fr \\ 2 School of History, Classics and Archaeology, University of Edinburgh, UK \\ C.Bonsall@ed.ac.uk
}

\begin{abstract}
This paper discusses why large areas of the central and northern Balkans lack evidence of Mesolithic settlement and what implications this holds for future research into the Neolithization of the region. A marked shift in site distribution patterns between Upper Palaeolithic and Mesolithic is interpreted as a response to changing environmental conditions and resource availability. It is suggested that some important questions of the pattern, processes and timing of the transition to farming across the Balkan Peninsula may only be answered through new archaeological surveys of the Lower Danube valley and exploration of submerged landscapes along the Black Sea, Aegean and Adriatic coasts.
\end{abstract}

IZVLEČEK - V članku razpravljamo o vzrokih za pomanjkanje dokazov o mezolitski poselitvi velikega dela srednjega in severnega Balkana ter o posledicah, ki jih lahko imajo te ugotovitve za prihodnje raziskave neolitizacije v regiji. V poselitvenih vzorcih med poznim paleolitikom in mezolitikom smo prepoznali premik, ki ga razlagamo kot odziv na spremembe v okoljskih pogojih in razpoložljivosti naravnih virov. Predlagamo, da je mogoče na nekatera pomembna vprašanja, povezana z vzorci, procesi in ritmom prehoda h kmetovanju na Balkanskem polotoku, odgovoriti le z novimi arheološkimi pregledi Spodnjega Podonavja in z raziskovanjem potopljenih pokrajin ob obalah Črnega, Egejskega ter Jadranskega morja.

KEY WORDS - Balkans; Mesolithic; demographic change; Neolithization; exchange networks

\section{Introduction}

While there is general agreement that the Neolithic farming system was introduced to Southeast Europe from the Near East, just how farming reached and spread through the Balkans remains an important topic of discussion. Was agriculture brought in primarily by Anatolian farmers who replaced the resident hunter-gatherers, or did farming advance largely through the spread of ideas and technology rather than people? How many waves of expansion were there and what routes were followed?

In those areas where a Mesolithic presence has been documented - in parts of Greece, Dalmatia and the Iron Gates, for example - indigenous hunter-gather- ers are sometimes seen as active participants in the Neolithization process. Conversely, where the Mesolithic has proved difficult to identify (as in Bulgaria) the Neolithic is assumed to have begun with the arrival of immigrant farmers who entered a landscape that was 'almost completely uninhabited in the early Holocene' (Todorova 1995.82).

In this paper we consider why large areas of the central and northern Balkans, especially Bulgaria, lack evidence of Mesolithic settlement and what implications this holds for future research into the Neolithization of the region. 


\section{Where were the foragers?}

In the context of a discussion of forager-farmer interactions, Marek Zvelebil and Malcolm Lillie (2000) published a map of Southeast Europe on which they proposed several 'areas of concentrated hunter-gatherer settlement' north of the Aegean (Fig. 1). In the central and northern Balkans areas of high Mesolithic population density were identified in the Iron Gates of the Danube, the northeast Adriatic and upper Sava River catchment, the southern Dinaric Mountains, and the Danube Delta and neighbouring Black Sea littoral.

The only one of these 'population clusters' for which there is strong

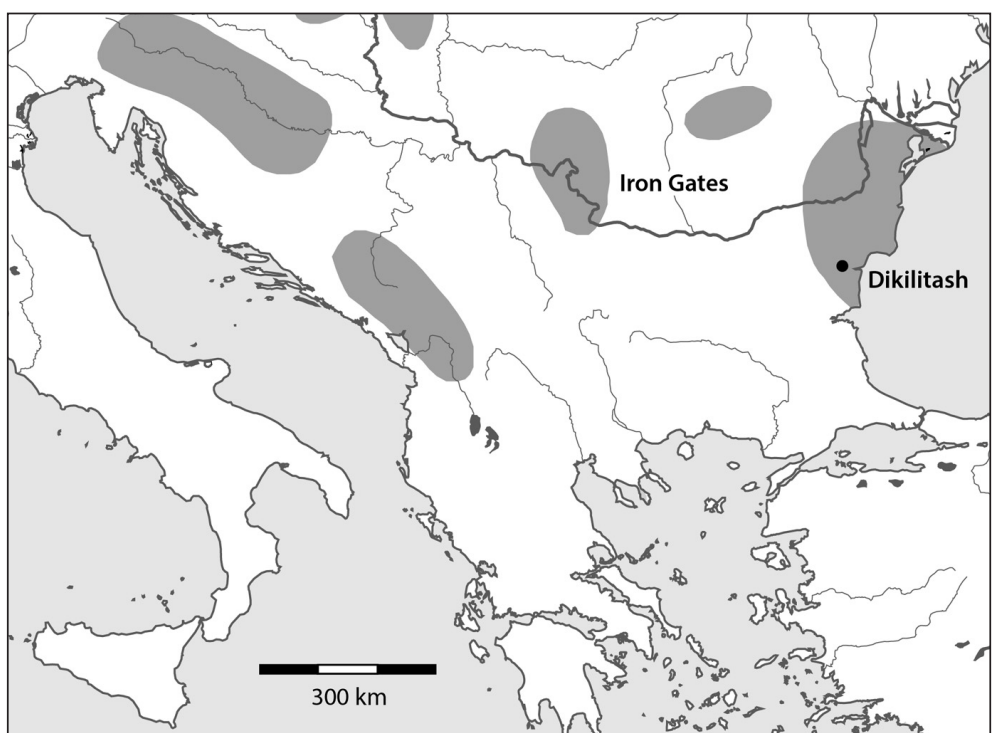

Fig. 1. 'Areas of concentrated hunter-gatherer settlement' in Southeast Europe (after Zvelebil, Lillie 2000.Fig. 3.4). supporting evidence is the Iron Gates, where some twenty Mesolithic sites have been identified along the banks of the Danube in Romania and Serbia, the majority of which also have Early Neolithic occupations (Boroneant, Bonsall 2012.Fig. 1; Borić, Price 2013). Of the other Mesolithic 'population clusters', the northeast Adriatic and Dinaric Mountains are represented mainly by cave and rockshelter sites; there are no large open-air sites equivalent to those in Iron Gates.

Zvelebil and Lillie's 'Danube Delta-Black Sea cluster' appears to rest on the evidence of occasional finds of supposedly Mesolithic artefacts from Romanian Dobrogea (Bolomey 1978; Păunescu 1987) and the Pobitite Kamani (Dikilitash) area some $20 \mathrm{~km}$ to the west of Varna in northeast Bulgaria (Dzhambazov, Margos 1960; Gatsov 1989). The Pobitite Kamani area is an extensive heathland developed on Lower Eocene sands. Lithic artefacts were collected from surface blow-outs and erosion scars over an area of more than $50 \mathrm{~km}^{2}$, and the assemblage of over 12000 artefacts is generally regarded as a 'palimpsest' resulting from human activity at different time periods. Several authors have identified a 'Mesolithic' component within the assemblage, including microliths. Published illustrations indicate the presence of curved backed and geometric forms (including trapezes). The curved backed pieces and some geometric elements find their closest Balkan parallels in the Epigravettian, notably at sites in the Iron Gates reach of the lower Danube valley (Gatsov 1989). The trapezes from Pobitite Kamani often have straight truncations and appear to have been made on blades. In the Balkans trapezes of this type are characteristic of the Final Mesolithic ('Castelnovian') of the circum-Adriatic region, which has been interpreted as a region-specific tradition that originated in North Africa (Perrin 2012). To the east of the Dinaric Mountains, however, blade and trapeze industries appear to be absent from Late Mesolithic contexts, for example from sites along the Lower Danube in the Iron Gates (C. Bonsall, pers. obs.). In contrast trapezes with straight truncations and made on blades are a frequent component of Early and Middle Neolithic sites throughout the Balkans (e.g., Lichardus et al. 2000; Zlateva-Uzunova 2009; Gurova 2014). The trapezes that occur sporadically in the Mesolithic of Franchthi Cave in the Peloponnese differ in that they are often made on flakes ( $v s$ blades) and have sinuous truncations (Perlès 2001). The balance of probability, therefore, is that the trapezes from Pobitite Kamani are of Neolithic and not Late Mesolithic date.

\section{The bigger picture}

Figure 2 compares the locations of radiocarbon dated Upper Palaeolithic (c. 40-11.7 ka calBP) and Late Mesolithic (c. 9.2-8.0 ka calBP) sites in the Balkans. The map is based on published sources that were available to us at the time of the Ljubljana Seminar in 2013. The list of sites may not be exhaustive, but we suggest the overall picture is broadly representative.

The respective distributions are strikingly different. Upper Palaeolithic sites (the majority of them in 


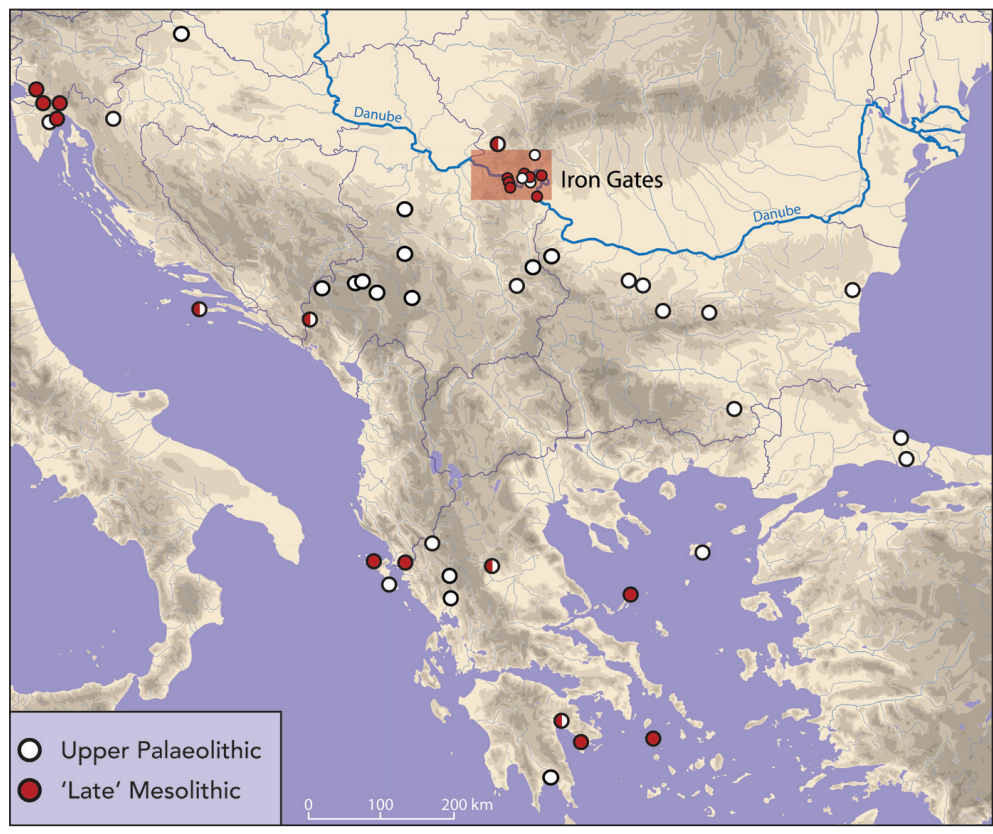

Fig. 2. ${ }^{4} \mathrm{C}$ dated Upper Palaeolithic and Late Mesolithic sites in the Balkans.

caves or rockshelters) are found in most areas of the Balkans, including deep into the interior. In contrast, Late Mesolithic sites have a distinctly peripheral distribution within the Balkans, most sites being located within $50 \mathrm{~km}$ of the sea or the Danube (by far the largest river in the region).

The absence of Mesolithic sites from large areas of the Balkans has sometimes been attributed to a lack of research - including an emphasis on cave investigation at the expense of extensive, open-air survey - or the effects of geomorphological processes on site survival or visibility. To some extent, these factors must have affected Mesolithic site distributions. For example, the surveys and salvage excavations that led to the discovery of the Iron Gates sites between 1964 and 1983 did not extend downriver of the Iron Gates II dam, and this may account for the lack of Mesolithic (and indeed Early Neolithic) sites along the Bulgarian section of the lower Danube Valley. Where targeted surveys have been undertaken, as in parts of Greece (Runnels 2009), Albania (Runnells et al. 2004), Istria (Komšo 2006) and Slovenia (Frelih 1986; Mlekuž 2001), open-air Mesolithic sites have been discovered where previously only cave sites were known. However, this research has had little or no impact on the predominantly peripheral distribution of Late Mesolithic sites within the Balkans.

On the other hand, there are aspects of the Mesolithic distribution in the Balkans that are difficult to explain in terms of variable research intensity or taphonomic processes. One is the absence of Mesolithic remains from the many cave sites in Bulgaria that have produced evidence of Upper Palaeolithic occupation (Fig. 2) - sites that because of lower sea levels during the Last Glaciation were even further inland than they are today. Another is the 'Late Mesolithic gap' that is a common feature of radiocarbon sequences in caves located in peripheral areas of the Balkan Peninsula. Caves that were used in the Early Mesolithic often lack evidence of occupation during part or all of the Late Mesolithic. At Edera Cave in the Trieste Karst at the head of the Adriatic no activity is recorded between the end of the Early Mesolithic $c$. $9.0 \mathrm{ka}$ calBP and the earliest Neolithic $c .7 .6 \mathrm{ka}$ calBP (Biagi et al. 2008). Similarly, at Pupicina in Istria there is a gap of over 2000 years between the latest Mesolithic and earliest Neolithic occupations (Forenbaher, Miracle 2005; 2006; Forenbaher et al. 2013). Paolo Biagi and Michela Spataro (2001) attributed the radiocarbon gap' in sites like Edera and Pupićina to a general Mesolithic population decline and the disappearance of hunter-gatherers from whole areas of the Balkans.

There is a clear demographic trend from the Upper Palaeolithic to the Late Mesolithic in the Balkans. The various lines of evidence suggest that the interior of the Balkan Peninsula, which was extensively exploited in the Upper Palaeolithic, was not heavily populated by Mesolithic hunter-gatherers especially in the period after $c .9 .0 \mathrm{ka}$ calBP. However, this does not necessarily signify an overall population decline.

\section{Why the demographic shift?}

Palaeovegetation records for the Balkans (e.g., Huttunen et al. 1992; Connor et al. 2013; Magyari et al. 2013; Tonkov et al. 2014) show fluctuations between semi-desert, steppe and forest-steppe ecosystems between $c .37 .5$ and $10.5 \mathrm{ka}$ calBP, corresponding to the Upper Palaeolithic and initial Mesolithic, followed by a major expansion of temperate forest during the early Holocene (Fig. 3). Forest composition and canopy cover were strongly influenced by climate, altitude and soils, but crucially much of the 


\section{KUPENA II}

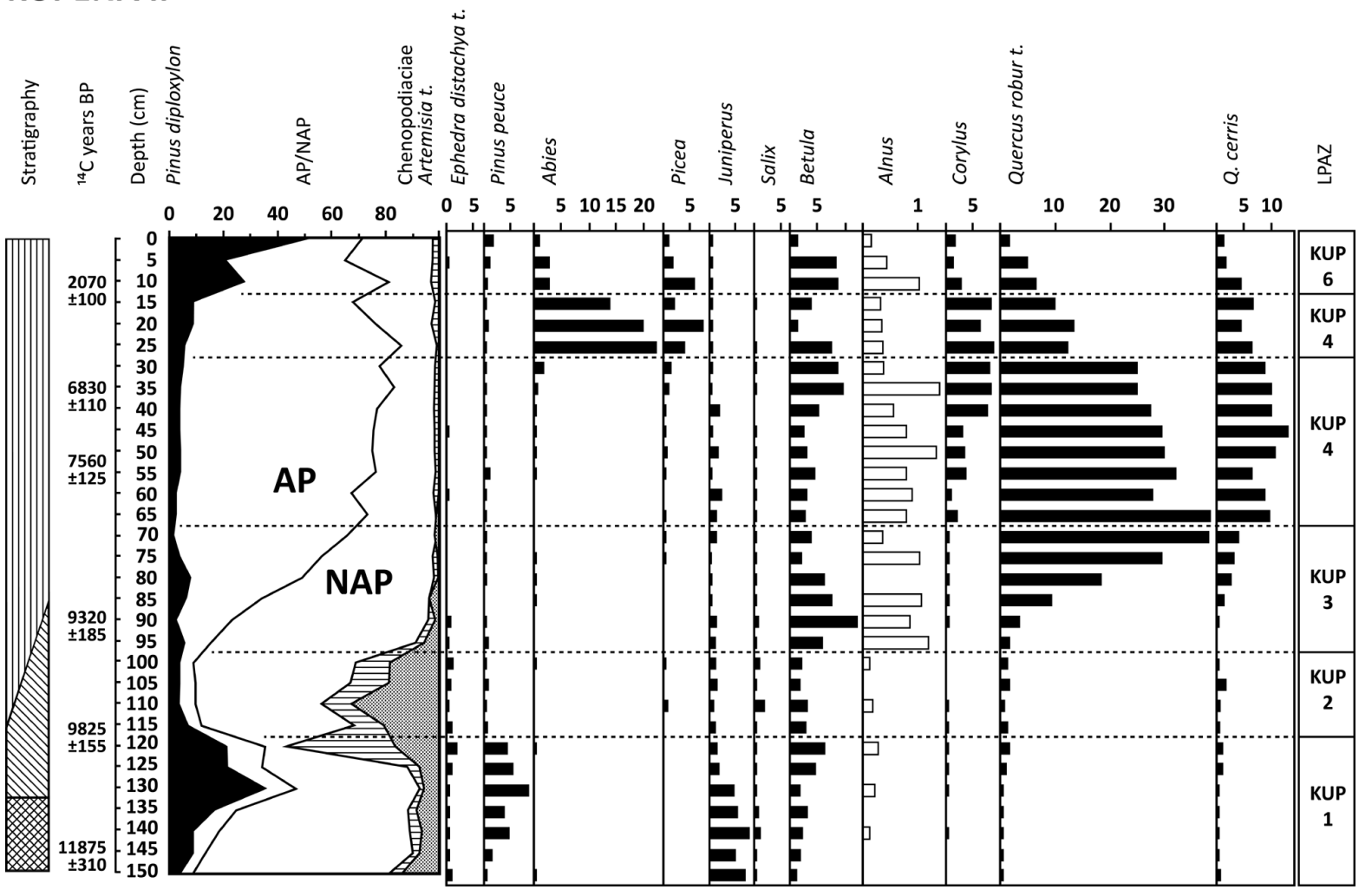

silty gyttja $\quad$ peaty gyttja

Fig. 3. Pollen diagram from Kupena II, western Rhodopes Mountains (redrawn from Huttunen et al. 1992).

central and northern Balkans below 700m a.s.1. was covered by closed canopy deciduous woodlands by $9.0 \mathrm{ka}$ calBP, if not earlier (Willis 1994).

Compared to steppe (grassland) environments, temperate forests have much lower ungulate biomass (Discamps 2014). Dense canopy cover also provides concealment for animals hence protection from predators, which further impacts on the productivity of hunting (Fig. 4). Closed canopy forest is also likely to have posed significant challenges for inter-group communication and participation in viable mating networks. Moreover, closed canopy forest is relatively poor in edible plants (Diamond 1997; contra Clarke 1976; Zvelebil 1994). In temperate forest ecosystems the highest ungulate and edible plant biomasses are found at forest margins, for example at the upland treeline, in areas recently burned by wildfires, or along sea, lake and river coasts and associated wetlands.

Overall, early Holocene forest expansion across the Balkans would have resulted in a substantial reduction in carrying capacity for human populations reliant on hunting and gathering. In some areas of Europe the reduction in animal biomass was com- pensated for by the availability of aquatic resources in inland rivers, lakes and wetlands. The Balkans, however, have few large rivers or navigable waterways; while lakes are comparatively few, often small and shallow, or at high elevations. The region lacks the numerous glacial lakes and connecting waterways of some other inland regions of Europe, which provided both aquatic food resources and communication routes for Mesolithic populations.

Across Mesolithic Europe as a whole there was a trend of increasing exploitation of aquatic resources against the background of early Holocene forest expansion. This trend is seen in site distribution patterns and archaeofaunal inventories, as well as in $\mathrm{C}$ - and $\mathrm{N}$-isotope values of human remains, to the extent that later Mesolithic populations in many parts of Europe are perhaps more accurately characterized as 'fishers' rather than hunter-gatherers.

Given the poverty of inland aquatic resources in the Balkans, the main demographic consequence of early Holocene forest expansion was most likely a redistribution of population from the interior toward sea and river coasts, with hunting activities concentrated at forest margins. 
Tasmania, a large island to the south of Australia, provides a striking ethno-archaeological example of human abandonment of a heavily forested interior in favour of the coast. Like the central and northern Balkans, Tasmania has a predominantly mountainous landscape and temperate climatic regime. In the southwest of the island the largely open scrub and heathland landscape of the Late Pleistocene was replaced by dense rainforest during the early Holocene (Colhoun et al. 1999). Although Late Pleistocene occupation of the interior is well documented (Lourandos 1997), ethnographic records indicate that at the time of European settlement in the early $19^{\text {th }}$ century the densely forested areas were not occupied by aboriginal peoples, who were concentrated in settlements along the coast (Plomley 1966).

In Southeast Europe evidence of Late Mesolithic coastal settlement is sparse and likely to be difficult to find owing to a general regional rise of sea level during the Holocene. The post-glacial sea level history of the Balkan coastline has been complicated by tectonic and isostatic factors (cf. Lambeck et al. 2004), but for the most part early Holocene shorelines lie below present sea level with the result that many shore-related Mesolithic and Early Neolithic sites on the Black Sea, Aegean and eastern Adriatic coasts will have been submerged or in many cases, perhaps, destroyed by marine erosion (Bailey 2007; Benjamin et al. 2011; Özdoğan 2011a).

The few sites along the Aegean and Adriatic coasts that show direct evidence of marine exploitation in the form of fish or shellfish remains, such as Franchthi, Maroulas and Sidari, occupied elevated positions above rocky shorelines, and some of these sites may have been 'field camps' ( $c f$. Binford 1980) or processing camps rather than residential base locations.

Currently, well-documented examples from the Balkans of Mesolithic shore-related settlements occur mainly in the Iron Gates section of the Danube valley. Sites such as Padina, Vlasac and Schela Cladovei were hundreds or thousands of square metres in extent with architectural, burial and other evidence of permanent or semi-permanent occupation over centuries or millennia (Radovanović
1996; Boroneant 2012). Moreover, they were not just a Late Mesolithic phenomenon; paired AMS ${ }^{14} \mathrm{C}$ dating and stable isotope analyses of human remains indicate that fishing was practised in the Iron Gates (and probably along the entire length of the lower Danube) at least as early as the Late Palaeolithic, became increasingly important during the Mesolithic, and was still significant economically during the Early Neolithic (Bonsall 2008; Borić 2011; Bonsall et al. 2012; 2015).

The Iron Gates sites have tended to be regarded as exceptional, yet paradoxically they may have been typical of Mesolithic and Early Neolithic coastal adaptations in Southeast Europe. Fishing villages or hamlets like those in the Iron Gates likely existed along the Bulgarian section of the Lower Danube, as well as in protected embayments, lagoons and river estuaries along the Black Sea, Aegean and Adriatic coasts. As Douglass Bailey observed: "If the rise in the Black Sea removed from the region's landscapes a large coastal plain ... then that flooded plain must contain much of the missing pre-Neolithic record, perhaps in localized concentrations similar to what was found in the [Iron Gates] Gorges" (Bailey 2007.521).

Many sites may not have survived the Holocene marine transgression; others may lie at depths (or be covered in a thick layer of sediment) that make underwater archaeology difficult or impossible with

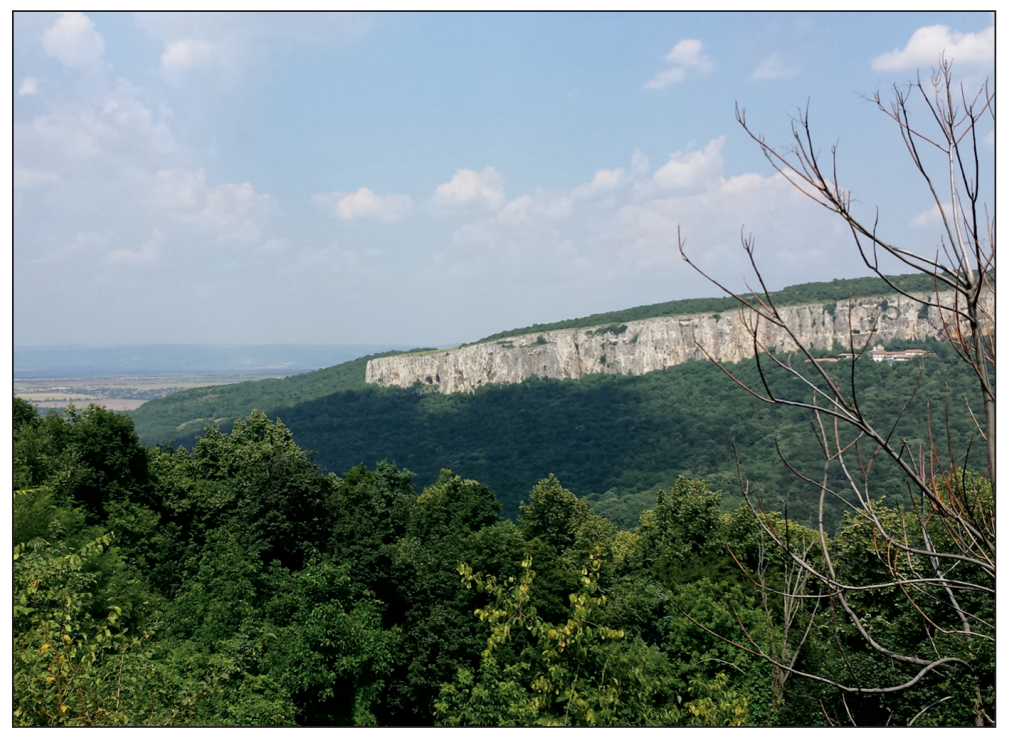

Fig. 4. Caves in the limestone cliff of Belyakovo Plateau, near Veliko Turnovo, Bulgaria. In the Upper Palaeolithic such sites provided convenient short-term shelters and good vantage points for watching game movements. In the heavily forested landscapes of the early Holocene this strategic advantage would have been lost (photo: Clive Bonsall). 
current technology. However, recent discoveries of submerged Neolithic settlements along the Mediterranean coast of Israel (Galili, Rosen 2011a; 2011b) and the northern shore of the Marmara Sea in Turkey (Özdoğan 2011a) at up to $12 \mathrm{~m}$ below sea level, suggest it is only a matter of time before submerged Late Mesolithic settlements are discovered around the Balkan coastline.

The pattern of coastal settlement and resource procurement likely varied regionally, influenced by the character of the coastline and resource availability. In contrast to the 'soft shore' environment of the Lower Danube, the Adriatic and Aegean coasts in particular provide extensive rocky shorelines, with more dispersed shellfish and fish resources. Mesolithic exploitation of such shorelines may have been similar to that in western Scotland where residential sites were located in protected embayments, and more remote areas of the coast were exploited using a logistical collecting strategy that involved the establishment of outlying fishing-and-processing camps, often taking advantage of the shelter (from sun, heat and rain) offered by coastal caves (Bonsall 1996; Bonsall et al. 2009).

The model of Pre-Neolithic settlement of the Balkans presented above, which envisages an increasing emphasis on aquatic resources and concentration of population in coastal fishing communities, does not preclude Late Mesolithic use of inland areas, especially where there were local concentrations of wetland and aquatic resources. But large areas of the interior with dense canopy cover and few aquatic resources may have been visited rarely or not at all.

\section{Fishers and farmers: implications for Neolithi- zation}

What role did coastlines and fishing communities play in the expansion of farming within the Balkans?

Most researchers accept that the spread of the Neolithic through the Aegean and the Mediterranean basin generally involved communities with a significant seafaring capability, and who probably combined farming with fishing and shellfish gathering. This model has been applied to the spread of the Impressed Ware Neolithic along the western shore of the Balkan Peninsula (e.g., Forenbaher, Miracle 2005).

Yet the Neolithization of the Balkans east of the Dinaric Mountains is still seen by most researchers largely in terms of an overland spread initially following river valleys that led inland from the Aegean coast (e.g., Nikolov 1987; 1990; Lichardus-Itten 1993; Todorova, Vaysov 1993; Lichardus-Itten et al. 2002, 2006). Only a few researchers (e.g., Bailey 2007; Özdoğan 2011b) seem to have considered the possibility of an early maritime spread along the (now submerged) Black Sea coastal plain.

However, several lines of evidence, concrete and circumstantial, favour this possibility:

(1) The lack of Early Neolithic sites along the Black Sea coast probably has more to do with geological processes and our inability to locate sites, than a lack of interest in coasts and coastal resources by early farmers.

(2) Some of the earliest known Neolithic communities in the southern Balkans and neighbouring parts of western Anatolia combined farming with the exploitation of coastal resources, for example at Fikirtepe (Düring 2011), Yeşilova (Derin 2008) and Franchthi (Perlès et al. 2013).

(3) The earliest known Neolithic sites in the Balkans interior (Fig. 5) are several centuries younger than the earliest known sites in mainland Greece and the Aegean. Moreover, the similarity of the earliest Neolithic $14 \mathrm{C}$ dates (6100-6000 calBC) across the Balkans from southern Bulgaria to Transylvania (a straight-line distance of $c .600 \mathrm{~km}$ ), is difficult to explain purely in terms of a south-north overland spread. A simultaneous expansion along the Black Sea littoral and river valleys leading inland from the Black Sea - including those of the Danube and its southern and northern tributaries - would fit better with the radiocarbon record.

(4) For reasons discussed above, the densely forested interior may have proved as difficult for pioneer farmers as for hunter-gatherers. Therefore, an initial maritime/coastal spread aided by the availability of watercraft was arguably the easier option.

Pioneer colonization of the interior would have been difficult, if not impossible, without participation in 'interaction spheres' - loosely defined as information and exchange networks (cf. Caldwell 1964) through which pioneer farmers were able to maintain social and economic ties with established farming-fishing communities living in peripheral (coastal) areas. 


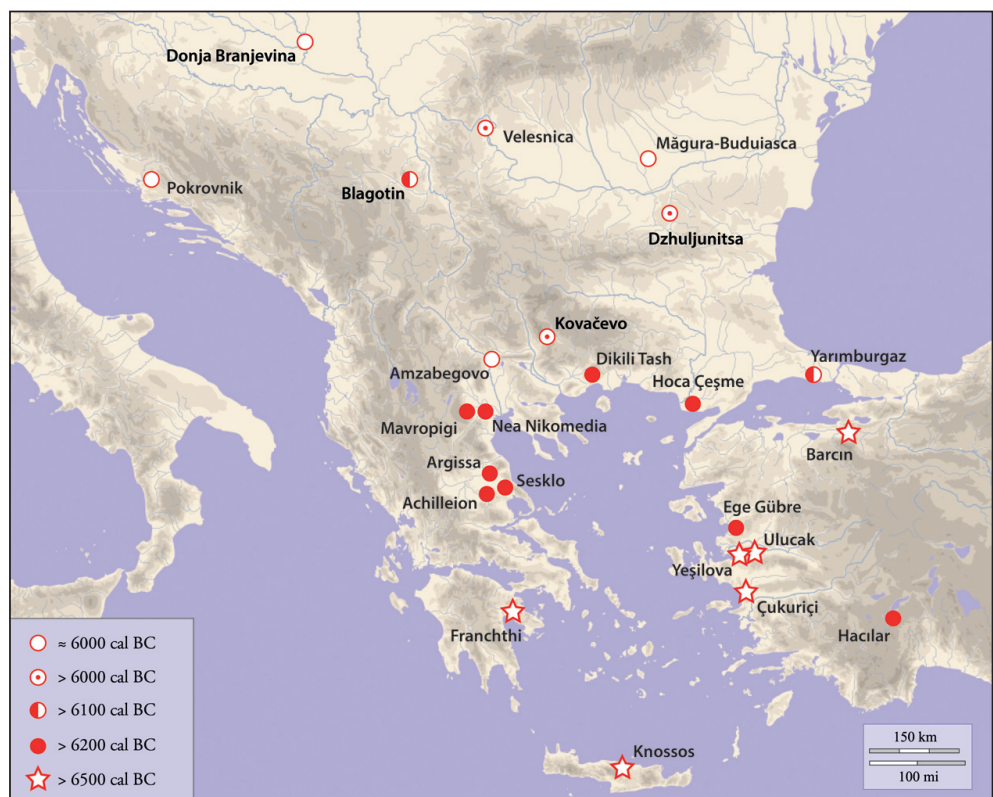

Fig. 5. Earliest radiocarbon dated evidence of farming in different parts of the Balkans-Aegean region.

Exchange networks operated among both Mesolithic and Early Neolithic groups in many parts of Europe, including the Balkans. In some cases there is evidence of the continuation of Mesolithic networks into the Neolithic. Marine shells used as body ornaments circulated widely among Upper Palaeolithic and Mesolithic groups in Southeast Europe (Cristiani et al. 2014) judging by evidence from Greece, the Adriatic coast and the Iron Gates. Shell ornaments were also exchanged during the Early Neolithic although the forms and perforation techniques changed, reflected for example in the introduction of Spondylus ornaments and flat discoid beads made from marine bivalve shells (Séfêriadès 1995; Perlès 2001).

The existence of an important interaction sphere in the southern Balkans at the Meso-Neolithic transition is reflected in the distribution of obsidian originating from the Aegean island of Melos. Exploitation of this source necessitated the use of boats. Melian obsidian circulated among Late Upper Palaeolithic and Mesolithic groups on the Aegean islands and the Greek Mainland. Its use increased in the Early Neolithic - at Early Neolithic Argissa-Magoula (Greece) obsidian accounted for over one-third of the chipped stone tools - when it also appears in the eastern Aegean and western Anatolia. In a thought-provoking paper, Agathe Reingrüber (2011) has argued that the archaeological distribution of Melian obsidian is indicative of a network of seafaring groups that was already in existence in the Mesolithic and continued into the Neolithic, and which was crucial in the spread of farming across the Aegean into mainland Southeast Europe.

In the Late Mesolithic and Early Neolithic Balkans north of Greece obsidian is scarce, and its provenance uncertain. The very limited amount of material found on Early Neolithic sites in the central and northern Balkans east of the Dinaric Mountains may all come from sources in the Carpathians rather than Melos (Williams-Thorpe et al. 1984; see also Tripković 2004).

In Early Neolithic Bulgaria, Serbia and southern Romania the 'demand' for high quality lithic materials was largely satisfied by yellowish-brown flint with white or pale-brown 'spots', often referred to in the archaeological literature as 'Balkan flint'. This high quality material often dominates chipped stone assemblages of the Karanovo I-II and Starčevo-Körös-Criş cultures.

Early Neolithic use of Balkan flint has been most intensively studied in Bulgaria (Fig. 6; Gurova 2008;

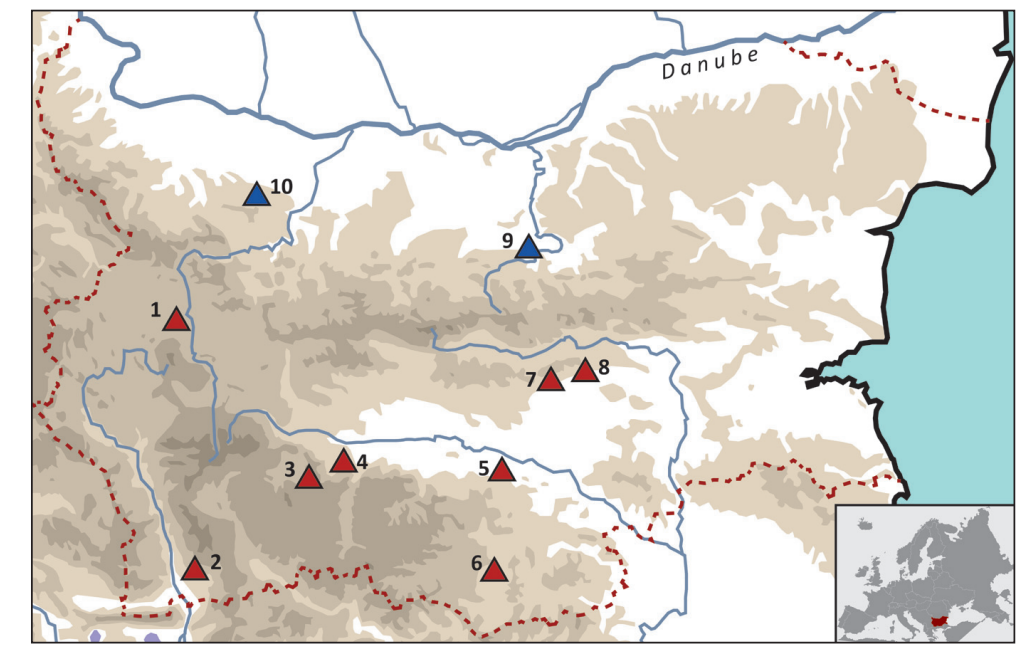

Fig. 6. Bulgarian Early Neolithic sites with Balkan flint artefacts (all sites) and 'formal toolkits' (red triangles): 1 - Slatina; 2 - Kovačevo; 3 - Rakitovo; 4 - Kapitan Dimitrievo; 5 - Yabalkovo; 6 Sedlare; 7 - Azmak; 8 - Karanovo; 9 - Dzhuljunitsa; 10 - Ohoden (revised after Gurova 2008.Fig. 1). 

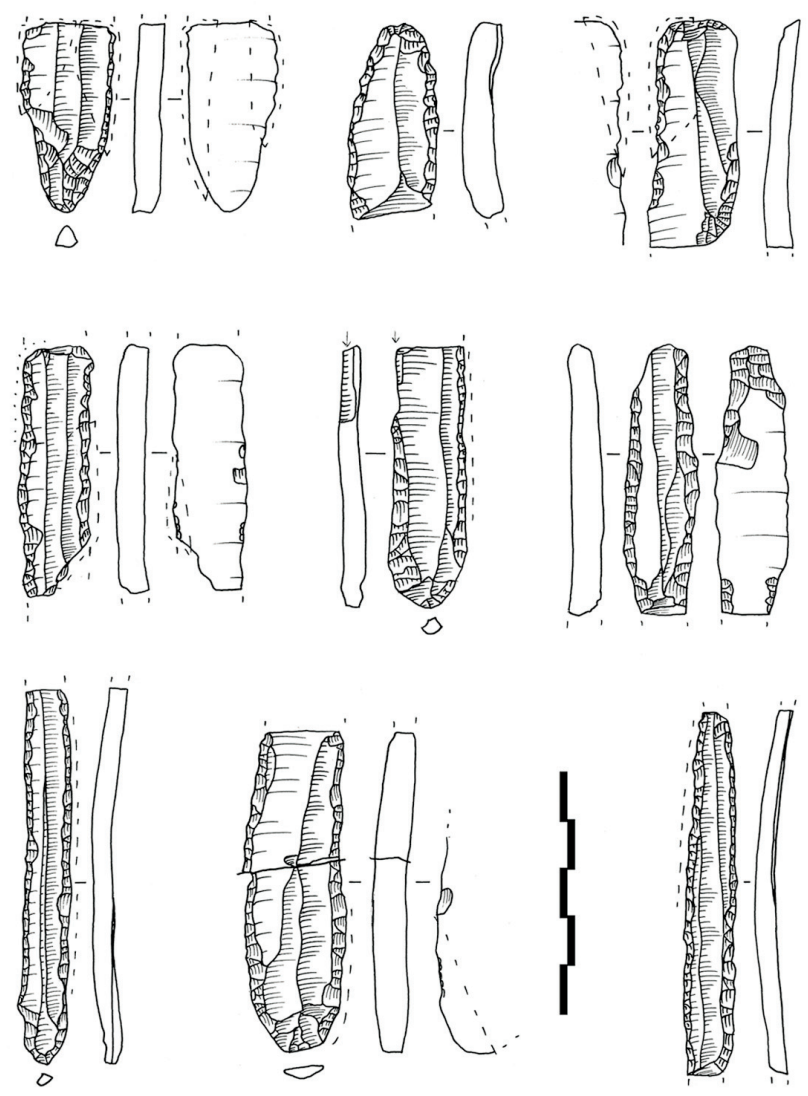

1
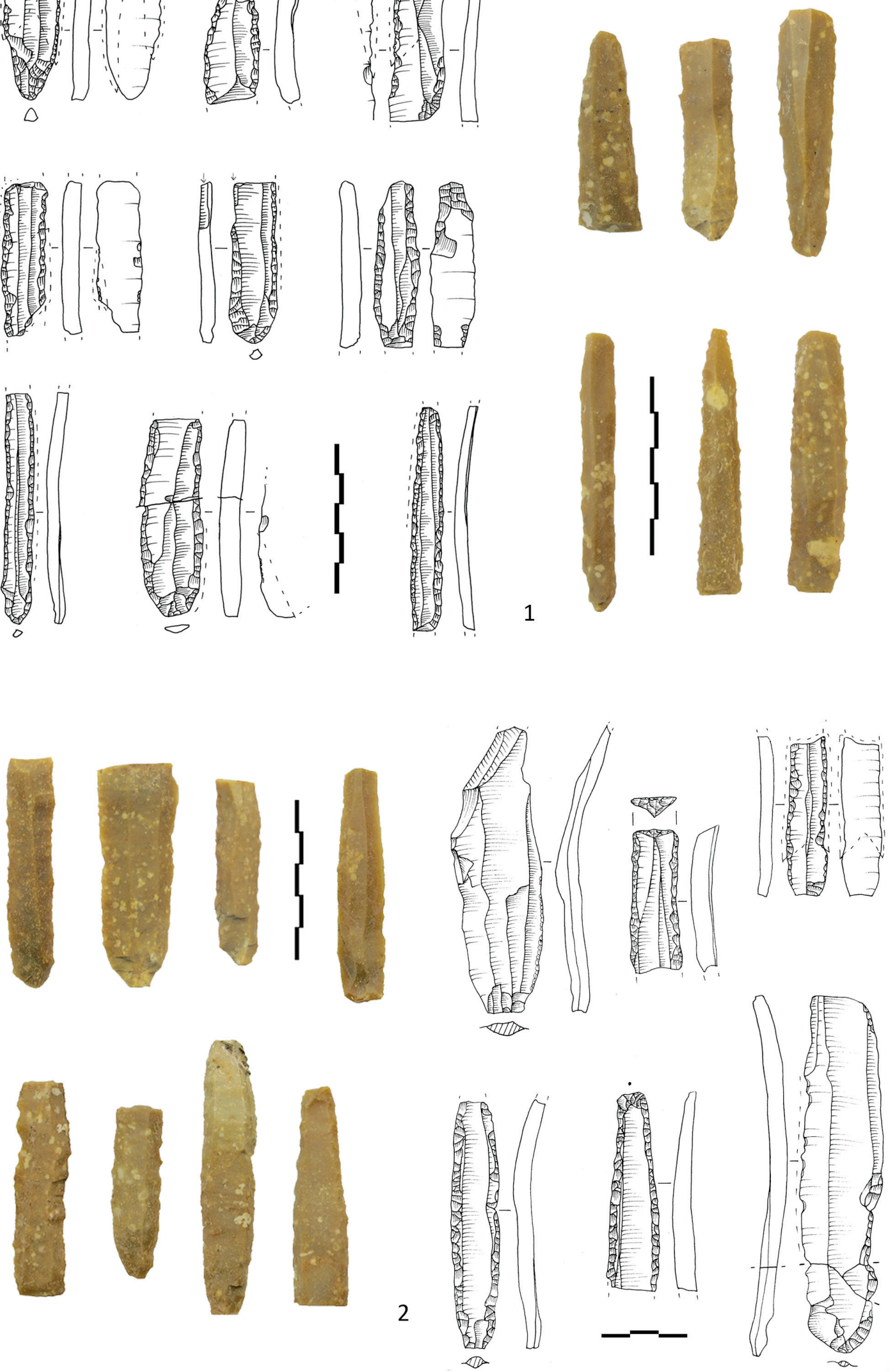

Fig. 7. Balkan flint formal toolkit from the Early Neolithic sites of Yabalkovo (1) and Slatina (2) (Photo and drawings: $M$. Gurova). 
2011; 2012a; 2012b; Gurova, Nachev 2008). The Balkan flint component of Karanovo I-II culture lithic assemblages is characterized by what Maria Gurova has termed a 'formal toolkit' with a distinctive suite of retouched tools made on large regular blades produced by punch technique. The formal tools comprise blades with continuous (sometimes partial) semi-abrupt to abrupt retouch along one or both lateral edges, sometimes with pointed or rounded retouched ends, as well as sickle inserts (Figs. 7 and 8) (Gurova 2008). The sudden appearance of this highly developed lamellar (sometimes misleadingly termed 'macroblade') industry remains one of the most intractable problems of the Balkan Neolithic (Koztowski 2007.49).

The repetition of the Balkan flint 'formal toolkit' over such a large territory and its co-occurrence with other distinctive socio-cultural traits between c. 5900-5600 calBC, implies the existence of a sophisticated exchange network with a high degree of interaction.
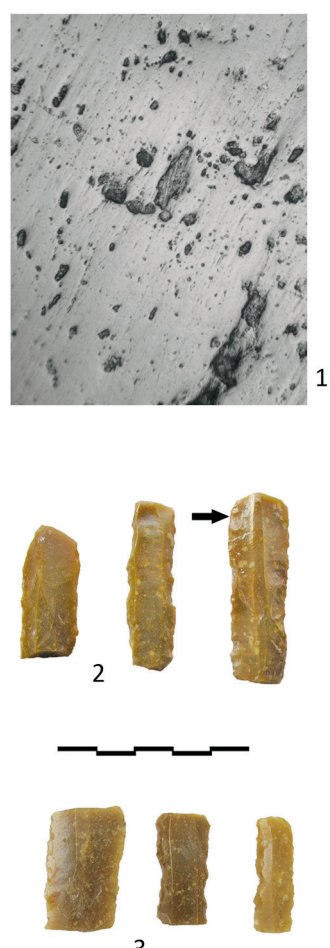

3

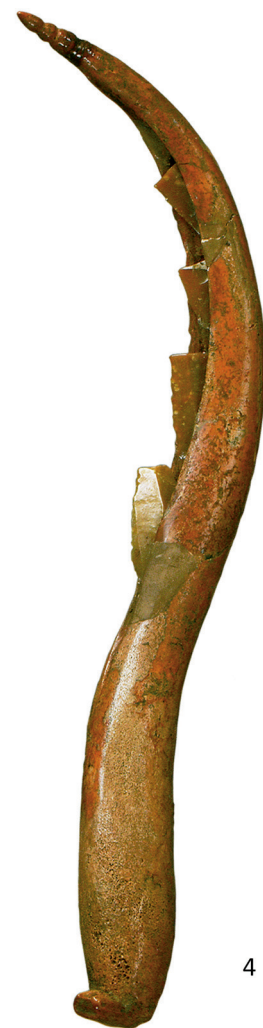

4

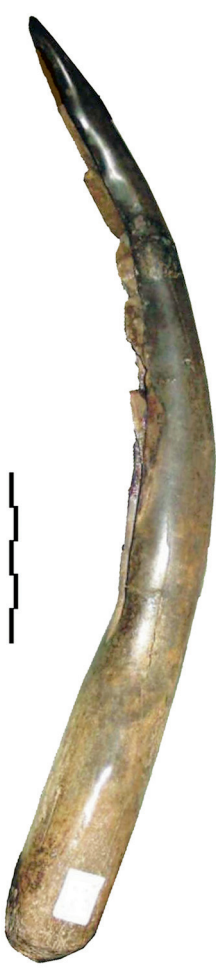

Fig. 8. Early Neolithic sickles with Balkan flint inserts: 1 microphotographs of typical cereal polish (x 100); 2 sickle inserts from Kovačevo; 3 sickle inserts from Yabalkovo; 4 sickles from Tell Karanovo (Figure: M. Gurova).
Considerable uncertainty surrounds the origin of the Balkan flint that was exploited by Early Neolithic groups in Bulgaria. Macroscopic, thin section and trace element analyses of archaeological and geological samples suggest that the most likely source or sources of the Balkan flint found at Karanovo I-II culture sites is in Cretaceous chalk-limestone formations of the Moesian platform in northern Bulgaria, most notably the Pleven-Nikopol region (Gurova, Nachev 2008; Bonsall et al. 2010; Gurova et al. in preparation 1 ).

'Pre-Karanovo I' use of Balkan flint is attested at the Early Neolithic site of Dzhuljunitsa $c .6050$ calBC (Fig. 9) (Gurova 2008; 2009; 2012a; 2012b). However, Balkan flint it seems did not occur in the earliest Neolithic occupation phase at Kovačevo in southwest Bulgaria (Gurova 2011), also dated to $c$. 6050 BC (Reingrüber, Thissen 2005; Higham et al. 2011). This very limited evidence may indicate that Neolithic use of Balkan flint began earlier in the north of Bulgaria than in the southwest.
But what were the origins of the Balkan flint interaction sphere? Did it originate with or after the arrival of farming in northern Bulgaria, or did Neolithic farmers take advantage of a pre-existing exchange network?

Much less is known of the exploitation of Balkan flint in Southeast Europe before the Neolithic. In Bulgaria the earliest documented archaeological occurrence was in the Gravettian and Epigravettian of Temnata Cave (Pawlikowski 1992). According to Dinan $(1996 a ; 1996 b)$ Balkan flint was also used in the Epigravettian of the Iron Gates. Whether it continued in use during the Iron Gates Mesolithic is problematic. Most sites in the Iron Gates also had Early Neolithic occupations; so the stratigraphic integrity of many 'Mesolithic' assemblages cannot be guaranteed and the characteristic features of Late Mesolithic assemblages in particular are hard to define.

The lack of Mesolithic sites in Bulgaria means that the extent of Balkan flint use during the early Holocene is unknown. But

\footnotetext{
1 A project entitled 'Prehistoric Flint Sourcing in NW Bulgaria and NE Serbia: field survey and laboratory analyses' was awarded in 2011 by the America for Bulgaria Foundation (ABF) and co-ordinated by the American Research Centre in Sofia (ARCS). The results are in preparation for publication by team members.
} 
if there were Mesolithic fishing villages along the Bulgarian section of the Danube (as argued above), it seems inconceivable that they would not have exploited the rich Balkan flint outcrops in the region - if only the alluvial placer deposits along the Danube at Nikopol on the Bulgarian shore (Fig. 10) and at Ciuperceni in Romania. Transport of this material by boat to settlements further down the Danube and along the Black Sea coast would have been relatively easy, but much more difficult upriver to the Iron Gates because of river speeds that in places exceeded $18 \mathrm{kph}$.

\section{Conclusions}

The lack of evidence for Late Mesolithic settlement over large areas of the Balkan Peninsula has simultaneously dictated the direction of research into the Neolithic transition in Southeast Europe and acted as a serious impediment to it.

In this paper we have presented a model of Pre-Neolithic settlement of the central and northern Balkans that envisages extensive exploitation of the Peninsula by Late Pleistocene hunter-gatherers, followed by increasing reliance on aquatic resources as post-glacial forest expansion led to a progressive reduction in ungulate biomass, with Mesolithic populations becoming concentrated in fishing villages along sea coasts and the lower courses of major rivers. This model does not preclude logistically-organized use of the near hinterland by Mesolithic groups operating from residential bases on the coast, but remote areas of dense, closed canopy forest were likely avoided.

Many Mesolithic coastal sites would have been inundated by the Holocene marine transgression. But sites like Schela Cladovei and Vlasac in the Iron Gates were perhaps typical of the Late Mesolithic fishing villages that once existed along the length of the Lower Danube and the Black Sea coast.

The earliest Neolithic settlements in the Balkans may also have been located along sea and river coasts and combined farming with fishing, as in the Iron Gates. Many of these sites, too, would have been inundated by marine transgression.

Rapid recolonization of the hinterland by farmers began before 6100 calBC, would have been initiated from population centres on sea and river coasts, and
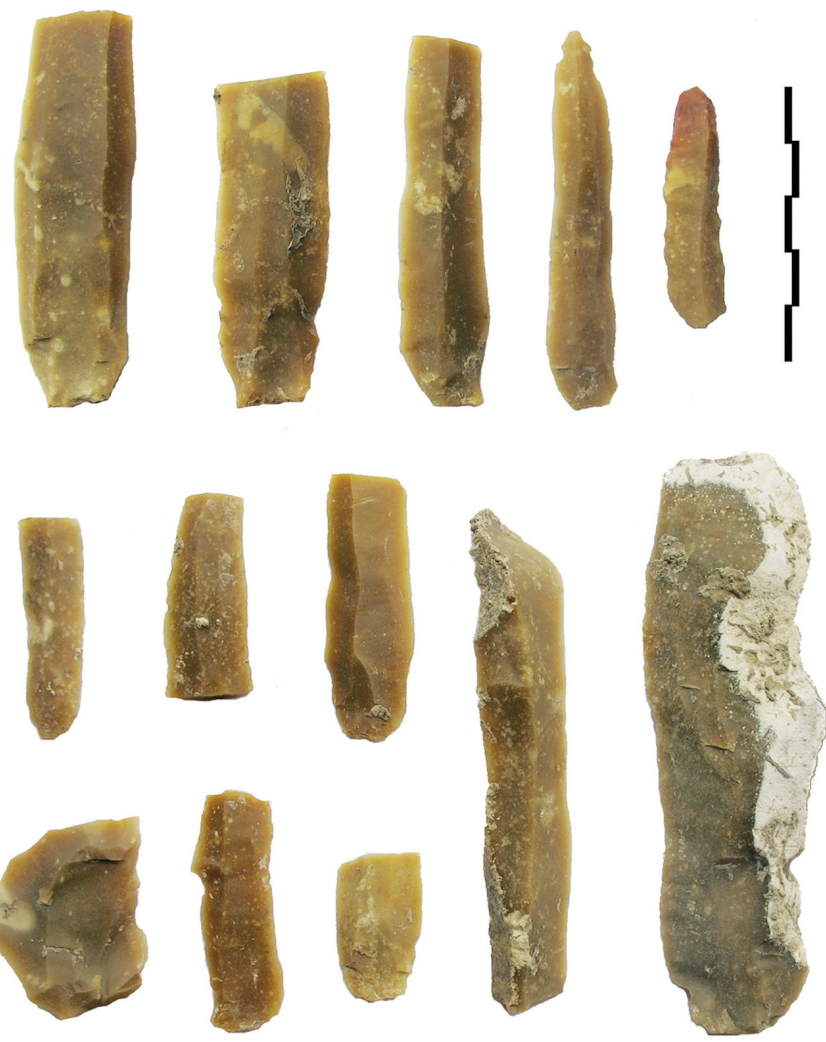

Fig. 9. 'Pre-Karanovo I' culture Balkan Flint artefacts (mainly debitage) from Dzhuljunitsa (Photo: M. Gurova).

was made possible by participation in established interaction spheres. One such exchange network had been operating in the Aegean since the Late Upper Palaeolithic, reflected in the distribution of Melian obsidian. We suggest there was also an exchange network involving Balkan flint (which may have originated in the Upper Palaeolithic) operating among Late Mesolithic groups in the Bulgarian section of the Danube valley and adjacent parts of Black Sea littoral, which expanded to encompass large areas of the central and northern Balkans during the Early Neolithic after 6000 calBC?

The current lack of information on the coastal aspect of early Holocene settlement of the Balkan Peninsula limits our ability to understand the processes involved in the transition to farming in the region. It follows that the future of Mesolithic and Early Neolithic studies in the Balkans, and Bulgaria in particular, may lie in targeted archaeological surveys of the Lower Danube valley downriver from the Iron Gates II dam and in systematic exploration of submerged landscapes along the Black Sea, Aegean and Adriatic coasts. 

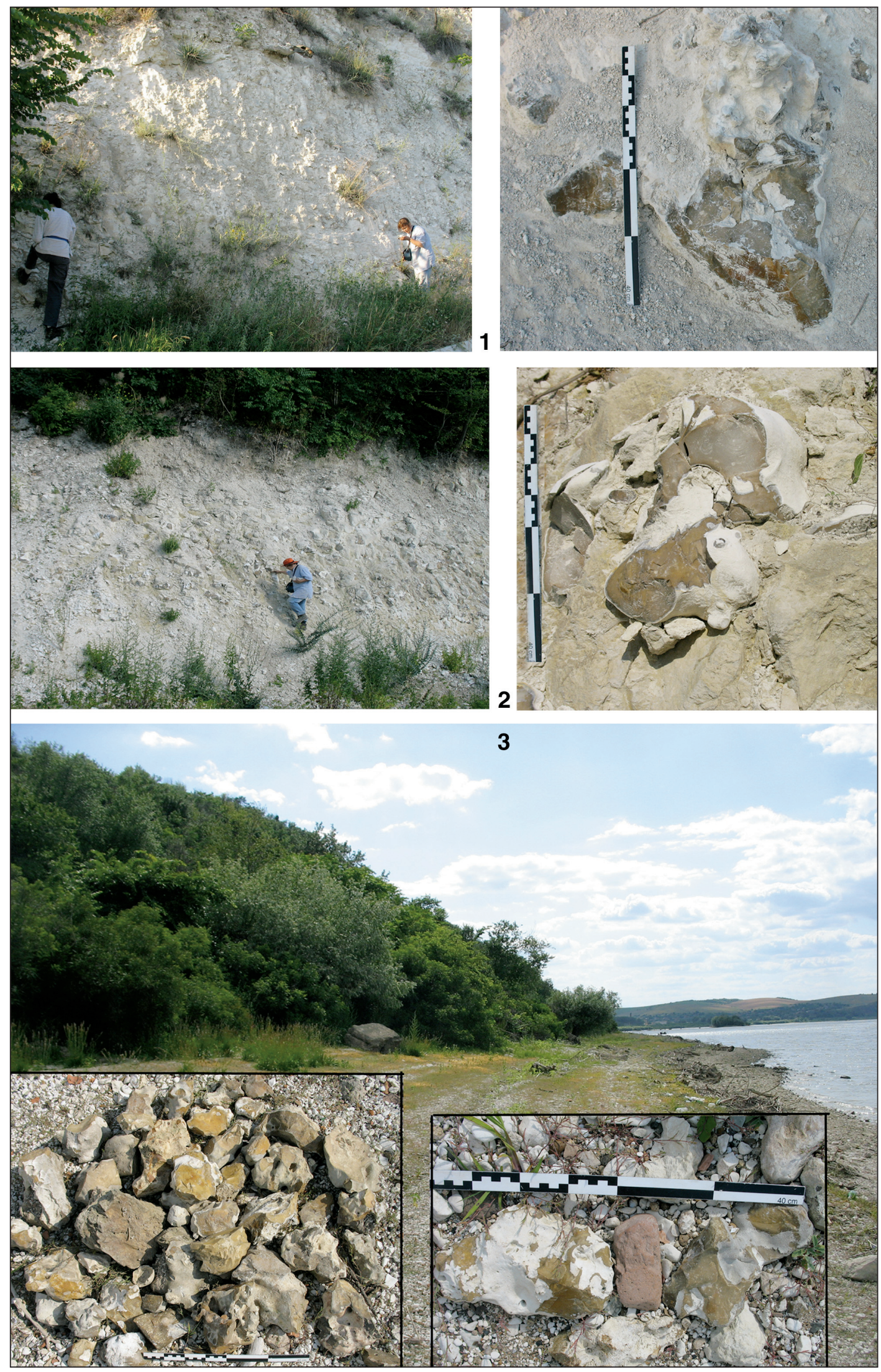

Fig. 10. Outcrops of Balkan flint near Nikopol: 1 Ali Koch Baba (Nikopol), flint nodules in a primary context in chalky limestone; 2 on the road SW from Nikopol, flint nodules in a primary context in chalky limestone; 3 Danube bank near Nikopol, secondary placer of flint concretions/nodules (after Gurova 2012.Fig. 13). 


\section{References}

Bailey D. W. 2007. Holocene changes in the level of the Black Sea: consequences at a human scale. In V. YankoHombach, A. S. Gilbert, N. Panin and P. M. Dolukhanov (eds.), The Black Sea Flood Question: Changes in Coastline, Climate and Human Settlement. Springer. Berlin: 515-536.

Benjamin J., Bekić L., Komšo D., Koncani Uhač I. and Bonsall C. 2011. Investigating the submerged prehistory of the eastern Adriatic: progress and prospects. In J. Benjamin, C. Bonsall, C. Pickard and A. Fischer (eds.), Submerged Prehistory. Oxbow. Oxford: 193-206.

Biagi P., Spataro M. 2001. Plotting the evidence: some aspects of radiocarbon chronology of the Mesolithic-Neolithic transition in the Mediterranean basin. Atti della Società per la Preistoria e Protostoria della Regione FriuliVenezia Giulia 12: 15-54.

Biagi P., Starnini E. and Voytek B. 2008. The MesolithicNeolithic transition in the Trieste Karst (north-eastern Italy) as seen from the excavations at the Edera Cave. In C. Bonsall, V. Boroneant and I. Radovanović (eds.), The Iron Gates in Prehistory. British Archaeological Reports IS 1893. Archaeopress. Oxford: 250-260.

Binford L. R. 1980. Willow smoke and dogs' tails: huntergatherer settlement systems and archaeological site formation. American Antiquity 45(1): 4-20.

Bolomey A. 1978. Why no Early Neolithic in Dobrogea? Dacia n.s. 22: 5-8.

Bonsall C. 1996. The 'Obanian' problem: coastal adaptation in the Mesolithic of western Scotland. In T. Pollard, A. Morrison (eds.), The Early Prehistory of Scotland. Edinburgh University Press. Edinburgh: 183-197.

2008. The Mesolithic of the Iron Gates. In G. Bailey, P. Spikins (eds.), Mesolithic Europe. Cambridge University Press. Cambridge: 238-279.

Bonsall C., Payton R., Macklin M. G. and Ritchie G. A. 2009. A Mesolithic site at Kilmore, near Oban, western Scotland. In N. Finlay, S. McCartan, N. Milner and C. Wickham Jones (eds.), From Bann Flakes to Bushmills: Papers in Honour of Professor Peter Woodman. Prehistoric Society Research Paper. Oxbow. 0xford: 70-77.

Bonsall C., Gurova M., Hayward C., Nachev C. and Pearce N. J. G. 2010. Characterization of 'Balkan flint' artefacts from Bulgaria and the Iron Gates using LA-ICP-MS and EPMA. Interdisciplinarni izsledvanija (Interdisciplinary Studies) 22-23: 9-18.
Bonsall C., Boroneant A., Soficaru A., Mcsweeney K., Higham T., Miritsoiu N., Pickard C. and Cook G. T. 2012. Interrelationship of age and diet in Romania's oldest human burial. Naturwissenschaften 99: 321-325.

Bonsall C., Vasić R., Boroneanț A., Roksandić M., Soficaru A., Mcsweeney K., Evatt A., Aguraiuja Ü., Pickard C., Dimitrijević V., Higham T., Hamilton D. and Cook G. 2015. New AMS ${ }^{14} \mathrm{C}$ dates for human remains from Stone Age sites in the Iron Gates reach of the Danube, Southeast Europe. Radiocarbon 57(1): in press.

Borić D. 2011. Adaptations and transformations of the Danube Gorges foragers (c. 13.000-5500 BC): an overview. In R. Krauß (ed.), Beginnings - New Research in the Appearance of the Neolithic Between Northwest Anatolia and the Carpathian Basin. Papers of the International Workshop $8^{\text {th }}-9^{\text {th }}$ April 2009, Istanbul. Organized by Dan Ciobotaru, Barbara Horejs and Raiko Krauss. Menschen-Kulturen-Traditionen 1. Studien aus den Forschungsclustern des Deutschen Archäologischen Instituts. Verlag Marie Leidorf. Rahden/Westfalen: 157-203.

Borić D., Price T. D. 2013. Strontium isotopes document greater human mobility at the start of the Balkan Neolithic. Proceedings of the National Academy of Sciences of the United States of America 110(9): 3298-3303.

Boroneanț A. 2012. Aspecte ale tranzitiei de la mezolitic la neoliticul timpuriu in zona Portile de Fier. Mage. Cluj-Napoca.

Boroneant A., Bonsall C. 2012. Burial practices in the Iron Gates Mesolithic. In R. Kogăniceanu, R. Curcă, M. Gligor and S. Stratton (eds.), HOMINES, FUNERA, ASTRA. Proceedings of the International Symposium on Funerary Anthropology 5-8 June 2011 '1 Decembrie 1918' University (Alba Iulia, Romania). Archaeopress. Oxford: 45-56.

Caldwell J. (ed.) 1964. Interaction Spheres in Prehistory. Illinois State Museum. Springfield.

Cristiani E., Farbstein R. and Miracle P. 2014. Ornamental traditions in the Eastern Adriatic: The Upper Palaeolithic and Mesolithic personal adornments from Vela Spila (Croatia). Journal of Anthropological Archaeology 36: 21-31.

Clarke D. L. 1976. Mesolithic Europe: the economic basis. In G. de G. Sieveking, I. H. Longworth and K. Wilson (eds.), Problems in Social and Economic Archaeology. Duckworth. London: 449-481.

Colhoun E. A., Pola J. S., Barton C. E. and Heijnis H. 1999. Late Pleistocene vegetation and climate history of Lake 
Selina, western Tasmania. Quaternary International 5758: 5-23.

Connor S. E., Ross S. A., Sobotkova A., Herries A. I. R., Mooney S. D., Longford C. and Iliev I. 2013. Environmental conditions in the SE Balkans since the Last Glacial Maximum and their influence on the spread of agriculture into Europe. Quaternary Science Reviews 68: 200-215.

Diamond J. 1997. Guns, Germs and Steel: A Short History of Everybody for the Last 13,000 years. Chatto \& Windus. London.

Discamps E. 2014. Ungulate biomass fluctuations endured by Middle and Early Upper Paleolithic societies (SW France, MIS 5-3): the contributions of modern analogs and cave hyena paleodemography. Quaternary International 337: 64-79.

Derin Z. 2007. Neolithic shellfish gathering at Yeşilova: an ethnoarchaeological view. In T. Takaoğlu (ed.), Ethnoarchaeological Investigations in Rural Anatolia. Vol. 4. Ege Yayınları. Istanbul: 1-6.

Dinan E. 1996a. A preliminary report on the lithic assemblage from the early Holocene level at the Iron Gates site of Băile Herculane. Mesolithic Miscellany 17(2): 15-24.

1996b. Preliminary lithic analysis of the Epigravettian levels from the Iron Gates site of Cuina Turcului. Mesolithic Miscellany 17(2): 25-40.

Düring B. S. 2011. The Prehistory of Asia Minor: From Complex Hunter-Gatherers to Early Urban Societies. Cambridge University Press. Cambridge.

Dzhambazov N., Margos A. 1960. Kam Vaprosa za Prouchvaneto na Paleolitnata Kultura v Raiona na Pobitite Kamani Dikilitash. Izvestia Bulgarskija Arheologičeski Institut 23: 269-295. (in Bulgarian)

Forenbaher S., Miracle P. T. 2005. The spread of farming in the Eastern Adriatic. Antiquity 79(305): 514-528.

Forenbaher S., Miracle P. T. 2006. Pupićina Cave and the spread of farming in the Eastern Adriatic. In P. T. Miracle, S. Forenbaher (eds.), Prehistoric Herders of Northern Istria: The Archaeology of Pupicina Cave. Vol. 1. Arheološki muzej Istre. Pula: 483-519.

Forenbaher S., Kaiser T. and Miracle P. T. 2013. Dating the East Adriatic Mesolithic. European Journal of Archaeology 16: 589-609.

Frelih M. 1986. Breg pri Škofljci - Mezolitsko najdišče na Ljubljanskem Barju (Breg near Škofljica. Mesolithic settle- ment at Ljubljana Marsh). Poročilo o raziskovanju paleolitika, neolitika in eneolitika v Sloveniji 14: 21-41.

Galili E., Rosen B. 2011a. Ancient underwater and coastal settlements of Israel: an endangered cultural resource. In H. Oniz, E. Aslan (eds.), SOMA 2009. Proceedings of the XIII Symposium on Mediterranean Archaeology, Selcuk University of Konya, Turkey 23-24 April 2009. British Archaeological Reports IS 2200. Archaeopress. Oxford: 57-66.

2011b. Submerged Neolithic settlements off the Carmel Coast, Israel: cultural and environmental insights. In J. Benjamin, C. Bonsall, C. Pickard and A. Fischer (eds.), Submerged Prehistory. Oxbow. Oxford: 272286.

Gatsov I. 1989. Early Holocene flint assemblages from the Bulgarian Black Sea coast. In C. Bonsall (ed.), The Mesolithic in Europe. John Donald. Edinburgh: 471-474.

Gurova M. 2008. Towards an understanding of Early Neolithic populations: a flint perspective from Bulgaria. $\mathrm{Docu}$ menta Praehistorica 35: 111-129.

2009. The flint factor in the Neolithization debate. In B. Petrunova, A. Aladzhov and E. Vasileva (eds.), Laurea. In honorem Margaritae Vaklinova. Vol. 2. National Archaeological Institute with Museum. Sofia: 1-14. (in Bulgarian).

2011. Early Neolithic site of Kovačevo: a case study of 'Balkan flint' formal toolkit. Studia Praehistorica 14: 71-81.

2012a. 'Balkan Flint' - fiction and/or trajectory to Neolithization: evidence from Bulgaria. Bulgarian e-Journal of Archaeology 1: 15-49. Available at http://www. be-ja.org

2012b. Establishing the identity of Bulgaria's first farmers - a new perspective. Archaeologia Bulgarica 16 (2): 1-26.

2014. Neolithic flint assemblages from Bulgaria: an overview. Samarskij naučnij vestnik 3(8): 94-108.

Gurova M., Nachev C. 2008. Formal Early Neolithic flint toolkits: archaeological and sedimentological aspects. In R. I. Kostov, B. Gaydarska and M. Gurova (eds.), Geoarchaeology and Archaeomineralogy. St Ivan Rilski. Sofia: 29-35.

Higham T. F. G., Bronk Ramsey C., Brock F., Baker D. and Ditchfield P. 2011. Radiocarbon dates from the Oxford AMS system: Archaeometry datelist 34. Archaeometry 53 (5): 1067-1084. 
Huttunen A., Huttunen R-L., Vasari Y., Panovska H. and Bozilova E. 1992. Late-glacial and Holocene history of flora and vegetation in the western Rhodopes Mountains, Bulgaria. Acta Botanica Fennica 144: 63-80.

Kozłowski J. K. 2007. Western Anatolia, the Aegean Basin and the Balkans in the Neolithization of Europe. In M. Spataro, P. Biagi (eds.), A Short Walk through the Balkans: the first farmers of the Carpathian basin and adjacent regions. Quaderno 12. Trieste Società per la Preistoria e Protostoria della Regione Friuli-Venezia Giulia. Trieste: 39-52.

Komšo D. 2006. The Mesolithic in Croatia. Opuscula Archaeologica 30: 55-92.

Lambeck K., Antonioli F., Purcello A. and Silenzi S. 2004. Sea-level change along the Italian coast for the past 10,000 yr. Quaternary Science Reviews 23: 1567-1598.

Lichardus-Itten M. 1993. La vallée du Strimon - une route au Néolithique ancien? In V. Nikolov (ed.), Praehistorische Funde und Forschungen: Festschrift zum Gedenken an Prof. Georgi I. Georgiev. Bulgarian Academy of Sciences. Sofia: 69-72.

Lichardus J., Gatsov I., Gurova M. and Iliev I. K. 2000. Geometric microliths from the Middle Neolithic site of Drama-Gerena (southeast Bulgaria) and the problem of Mesolithic tradition in south-eastern Europe. Eurasia Antiqua 6: 1-12.

Lichardus-Itten M., Demoule J.-P., Pernicheva L., GrębskaKulova M. and Kulov I. 2002. The site of Kovačevo and the beginnings of the Neolithic period in southwestern Bulgaria. The French-Bulgarian excavations 1986-2000. In M. Lichardus-Itten, J. Lichardus and V. Nikolov (eds.), Beiträge zu jungsteinzeitlichen Forschungenin Bulgarien. Saarbrücker Beiträge zur Altertumskunde 74. Dr. Rudolf Hebelt Verlag Gmbh. Bonn: 99-158.

2006. Kovačevo, an Early Neolithic site in south-west Bulgaria and its importance for European Neolithization. In I. Gatsov, H. Schwarzberg (eds.), Aegean - Marmara - Black Sea: The Present State of Research on the Early Neolithic. Proceedings of the Session held at the EAA $8^{\text {th }}$ Annual Meetingat Thessaloniki, 28th September 2002. Schriften des Zentrums für Archäologie und Kulturgeschichte des Schwarzmeerraumes 5. Beier \& Beran. Langenweissbach: 83-94.

Lourandos H. 1997. Continent of Hunter-Gatherers: New Perspectives in Australian Prehistory. Cambridge University Press. Cambridge.

Magyari E., Gaydarska B., Pettitt P. and Chapman J. 2013. Palaeo-environments of the Balkan Lateglacial and their potential - were humans absent from the Garden of Eden?
Bulgarian e-Journal of Archaeology 3: 1-30. Available at: http://www.be-ja.org

Mlekuž D. 2001. Floods and fires: landscape dynamics at Ljubljana Moor, Slovenia. In J. Fewster, M. Zvelebil (eds.), Ethnoarchaeology and Hunter-Gatherers: Pictures at an Exhibition. British Archaeological Reports IS 955. Archaeopress. Oxford: 43-52.

Nikolov V. 1987. The Strimon route in the Early Neolithic. Vekove 2: 39-47. (in Bulgarian)

1990. The problem of Central Balkan migration routes in the Early Neolithic: an interdisciplinary approach. Interdisciplinarni izsledvanija (Interdisciplinary Studies) 17: 9-24. (in Bulgarian)

Özdoğan M. 2011a. Submerged sites and drowned topographies along the Anatolian coasts: an overview. In J. Benjamin, C. Bonsall, C. Pickard and A. Fischer (eds.), Submerged Prehistory. 0xbow. Oxford: 219-229.

2011b. Archaeological Evidence on the westward expansion of farming communities from eastern Anatolia to the Aegean and the Balkans. Current Anthropology 52(S4): S415-S430.

Păunescu A. 1987. Tardenoisianul din Dobrogea. Studii si Cercetari Istorie Veche și Archeologice 38: 25-41.

Pawlikowski M. 1992. The origin of lithic raw materials. In J. K. Kozłowski, H. Laville and B. Ginter (eds.), Temnata Cave: Excavations in Karlukovo Karst Area Bulgaria. Jagiellonian University Press. Kraków: 241-288.

Perlès C. 2001. The Early Neolithic in Greece: The First Farming Communities in Europe. Cambridge University Press. Cambridge.

Perlès C., Quiles A. and Valladas H. 2013. Early seventhmillennium AMS dates from domestic seeds in the Initial Neolithic at Franchthi Cave (Argolid, Greece). Antiquity 87(338): 1001-1015.

Perrin T. 2012. Les derniers chasseurs-cueilleurs européens. Les Dossiers d'Archéologie 353: 26-31.

Plomley N. J. B. (ed.) 1966. Friendly Mission: The Tasmanian Journals and Papers of George Augustus Robinson, 1829-1834. Tasmanian Historical Research Association. Hobart.

Radovanović I. 1996. The Iron Gates Mesolithic. International Monographs in Prehistory. Ann Arbor. Michigan.

Reingrüber A. 2011. Early Neolithic settlement patterns and exchange networks in the Aegean. Documenta Praehistorica 38: 291-305. 
Reingrüber A., Thissen L. 2005. ${ }^{14} \mathrm{C}$ database for the Aegean catchment (eastern Greece, southern Balkans and western Turkey) 10.000-5500 cal BC. In C. Lichter (ed.), How Did Farming Reach Europe? Anatolian-European relations from the second half of the 7 th through the first half of the $6^{\text {th }}$ millennium cal BC. BYZAS 2. Veroffentlichung des Deutschen Archaeologischen Instituts Istanbul. Ege Yayinları. Istanbul: 295-327.

Runnels C. 2009. Mesolithic sites and surveys in Greece: a case study from the southern Argolid. Journal of Mediterranean Archaeology 22(1): 57-73.

Runnels C., Korkuti M., Galaty M., Timpson M. E., Whittaker J. C., Stocker S. R., Davis, J. L., Bejko L. and Muçaj S. 2004. The Palaeolithic and Mesolithic of Albania: survey and excavation at the site of Kryegjata B (Fier District). Journal of Mediterranean Archaeology 17(1): 3-29.

Séfèriadès M. L. 1995. Spondylus gaederopus: the earliest European long distance exchange system - a symbolic and structural archaeological approach to Neolithic societies. Poročilo o raziskovanju paleolitika, neolitika in eneolitika v Sloveniji 22: 238-245.

Todorova H. 1995. The Neolithic, Eneolithic and Transitional Period in Bulgarian prehistory. In D. W. Bailey, I. Panayatov (eds.), Prehistoric Bulgaria. Prehistory Press. Madison: 79-98.

Todorova H., Vajsov I. 1993. The Neolithic in Bulgaria. Nauka i Izkustvo. Sofia. (in Bulgarian).
Tonkov S., Lazarova M., Bozilova E., Ivanov D. and Snowball I. 2014. A 30,000-year pollen record from Mire Kupena, western Rhodopes Mountains (south Bulgaria). Review of Palaeobotany and Palynology 209: 41-51.

Tripković B. 2004. Obsidian deposits in the central Balkans? Tested against archaeological evidence. Starinar 53-54: 163-179.

Williams-Thorpe 0., Warren S. E. and Nandris J. G. 1984. The distribution and provenance of archaeological obsidian in Central and Eastern Europe. Journal of Archaeological Science 11: 183-212.

Willis K. J. 1994. The vegetational history of the Balkans. Quaternary Science Reviews 13: 769-788.

Zlateva-Uzunova R. 2009. Early Neolithic Stone Assemblage From Ohoden - Valoga Site, Building No.1. In G. Ganetsovski (ed.), Ohoden: a site from the Early Neolithic, excavations 2002-2006. Craft House Bulgaria. Sofia: 6375.

Zvelebil M. 1994. Plant use in the Mesolithic and its role in the transition to farming. Proceedings of the Prehistoric Society 60: 35-74.

Zvelebil M., Lillie M. 2000. Transition to agriculture in Eastern Europe. In T. D. Price (ed.), Europe's First Farmers. Cambridge University Press. Cambridge: 57-92. 
